\title{
INDONESIA'S RESPONSE TO ILO 185 CONVENTION AN ANALYSIS
}

\author{
Firman Hasan*
}

\begin{abstract}
To protect its labour who work overseas Indonesia has initiated cooperation with some Middle Eastern countries and some organizations such as United Nations High Commission on Refugees (UNHCR) and International Organization of Migration (IOM). ILO Convention 185/2003 has been put in place as a result of the American pressure on the International Labour Organisation (ILO). While the benefits of the convention are difficult to deny there are also concerns about its potential abuse and other problems arising from its implementation.
\end{abstract}

\section{INTRODUCTION}

The classic theory of Hans Morgenthau states that the "dignity" of a country in legal or political relationships depends on what he calls the Element of National Power. He classifies these elements into two categories: relative stable and constant to change. ${ }^{1}$ Actually, these nine elements of national power can be classified into two major groupings

Senior Lecturer, Faculty of Law, Andalas University, Indonesia.

Hans J. Morgenthau, (1973) Politics Among Nations, Alfred A Knopf Inc. New York, p. 117. 
namely; "Human Resources" consisting of seven elements ${ }^{2}$ and "Natural Resources" consisting of two elements. ${ }^{3}$ These elements determine "a bargaining position" of a country in international relations.

Both in classical international relations and in the actual condition nowadays, human resources are more dominant in determining a country's "standing position" than natural resources. This paper will discuss two aspects of human resources namely population and quality of diplomacy, especially from the perspective of Indonesian's international relations. Population in this paper refers to the Indonesian people and the quality of diplomacy refers to this country's international relations. However it is important to know that what the writer means by the two categories above is not semantically the same as that of Morgenthau. There is a narrowing of the category and problem which the writer thinks is still in line with Morgenthau's theory.

To clarify the above, these two elements will be examined in relation to the Department of Foreign Affairs where the diplomats of Indonesia gather, and also to Indonesian Overseas Workers (Tenaga Kerja Indonesia or TKI), both unskilled laborers and sailors who work in foreign ships around the world.

\section{THE ROLE OF THE FOREIGN AFFAIRS DEPARTMENT}

Most of Indonesia's international relationships are conducted by the Foreign Affairs Department of the Republic of Indonesia. The Department of Foreign Affairs has a coordinating role in the practice and implementation of international politics. The main goal of international relations and politics is to work for and to defend national interests, ${ }^{4}$

$2 \quad$ Industrial Capacity, Military Preparedness, Population, National Character, National Morale, Quality Diplomacy and Quality of Government quote ibid, p. 126-155.

3 Geography and Natural Resources ibid, p. 116-125.

$4 \quad$ In the New Order, it is stated that overseas politics is a continuation of domestic politics, see TAP MPR No V/1997 about GBHN. This is different from Yuwono Sudarsono's opinion that for a "strong" country that statement is valid, but ironically for a weak country the internal policy is "just" a response to the international dynamics. Compare with Hans Morgenthau's statement above in his Politics among Nations. 
including protection given to Indonesian citizens overseas. Both political activity and international relations based on national and international regulations are needed.

Pancasila is the nations's ideological foundation while the 1945 Constitution is its structural and conceptual foundation in the implementation and the conduct of international relations. The legal basis for the implementation of international politics and international relations is presently Regulation No. 37/1999 concerning International Relations and Regulation No. 24/2000 concerning International Agreement.

To give a clearer understanding, the International relations referred to here are all activities dealing with regional and international concerns that are conducted by the central and regional government, or its institutions, including state institutions, business corporations, political organizations, social organizations, non-governmental organizations (NGO), and Indonesia citizens. This definition places international relations in the public and private domain, and in a combination of the two.

As stated before, giving protection to Indonesian citizens in other countries is one of the main tasks of the Foreign Affairs Department of the Republic of Indonesia and the Indonesian Embassies overseas. This responsibility should be carried out in as effective a way as possible by the officials concerned. Article 19 (a), Rules and Regulation No. 37/ 1999 about international relations emphasizes that the Indonesian government should provide support, protection and legal assistance to its citizens and corporate bodies overseas in accordance with international regulations. This regulation also implies that the Indonesian authorities are obliged to protect an Indonesian worker overseas who gets into trouble, even though the worker has not previously reported to the relevant Indonesian authority. A similar sentence, article 92 paragraph (2) Rules and Regulation No. 39/2004 gives the same authority to the local Indonesian Embassy.

Protection and legal assistance for Indonesian citizens including workers (TKI), whether legal or undocumented, can not be given directly. It needs good cooperation and help bilaterally and multilaterally with the relevant authorities where they work or live, with international organizations and local social institutions and with individual foreigners

$5 \quad$ See section 78, verses 1 and 2 UU No. 39/2004 multilateral depends on the existence of agreement among countries with Indonesia especially for sailors in foreign ships. 
who care about Indonesian citizens. ${ }^{5}$ In giving protection to its citizens, Indonesia has made bilateral agreements as regards the placement of Indonesian workers with Kuwait, Jordan, Malaysia, South Korea, and Taiwan. ${ }^{6}$

An agreement with Singapore, Bahrain, United Arab Emirates, Qatar, Brunei Darussalam, and Australia is still in deliberation. The discussion is expected to be finalized in a short time.

The agreement with these countries aims to give better legal protection to poorly educated workers. However as reported by the mass media, violence still happens to Indonesian laborers, both legal and undocumented, who work abroad including in the countries which have signed the agreement with the Indonesian government.

Protecting the rights of Indonesian laborers (TKI) is crucially important. It is clear that the legal jurisdiction of the country which receives the foreign workers will be put in question by the demand from the Indonesian government for legal guarantees along with consular access if a worker has a legal problem. The host country will inevitably be more concerned about the interests of its own citizens rather than those of other countries.

This issue should not need to interfere with relations between Indonesia and the country where the Indonesian workers are facing problems since the cause lies not only with carelessness or intentional mistakes from the Indonesian side but also from the receiver country as well. Realizing this means that if an Indonesian laborer faces a legal problem, the judicial authority of the receiver country should be able to take into account the direct and indirect background to the problem and not just see the problem itself. However, the effort to find a solution to a legal problem, especially in giving legal protection to uneducated workers (legal or undocumented), is much better done in multilateral cooperation with international organizations such as International Labor Organization (ILO), United Nations High Commission on Refugees (UNHCR), International Organization of Migration (IMO) or with countries where

$6 \quad$ With Kuwait 10 May 1996, Malaysia renewed 10 May 2004, South Korea 13 July 2004. With Taiwan the agreement is between Indonesia Economic and Trade Office and Taiwan counterpart, to prevent One and Only one China policy-Director General of the Department of Foreign Affairs. 
many Indonesians are working. This multilateral cooperation has been carried out between Indonesia and ILO to formulate universal standard norms for the workers, while cooperation with the United Nations High Commission of Refugees has been established to help the Indonesian laborers if there is a conflict where they work.

To avoid over sensitivity by the receiver country, Indonesia has built cooperation with IOM to collect data which can (also) protect TKI (Indonesian laborers) from violence. This approach is expected to push the local government to "discipline” its citizens who employ foreign workers in their homes or businesses.

As a next step, Indonesia should find a general international legal umbrella to give legal protection to its citizens whenever they need it or when they are facing a legal problem in a foreign country.

\section{ILO CONVENTION 185 REGARDING SEAFARERS IDENTITY DOCUMENTS}

The terrorist attack on the World Trade Center in New York destroyed the twin towers through a direct strike by commercial planes. That attack on 11 September 2001, which is known as 9/11 (nine eleven) also hit the Pentagon, a defense center with the highest security in the world. Thousands of innocent victims died in that terrorist attack. ${ }^{7}$

That attack is the most tragic moment ever faced by the American people since the Japanese attack on the US navy in Pearl Harbor Hawaii on 7 December $1941 .{ }^{8}$ Before the $9 / 11$ incident, the paradigm that had always been held by the intelligence and defense analysts was that the United States of America was free from security threats within its territory and if there should occur an attack or interference from outside US territory, it would probably come from just a few countries such as Russia, North Korea, or China. That paradigm fell short of target since the attack came from outside America but it was carried out inside American

\footnotetext{
$7 \quad$ See $9 / 11$ commission report.

87 December 1945 was the day that will never be forgotten by the American people when the sudden attack was carried out at Pearl Harbor by the Navy and the Army of the Japanese empire. Pearl Harbor Attacked, http://pearlharborattacked.com/
} 
Territory by hijacking the commercial planes and flying them into buildings which symbolized the power of The United States of America in politics, economy and military. The attack had a huge effect psychologically making the people, or at least the American government, paranoid. ${ }^{9}$

To protect the people and the country, the US congress has passed anti- terrorist regulations which are very repressive and are known as the USA Patriot. These regulations require all the security and defense components of the United States to take immediate action to protect the nation and the country from all threats to security and defense of sea, land and air. This policy has grown out of control to the extent that the United States of America thinks it has a mandate to threaten and take action against other countries which have different policies to its own by accusing them of having developed nuclear weapons or by judging them to be undemocratic or to have acted against human rights or by accusing them of protecting terrorists or terrorism.

In order to sterilize the country from any potential disturbances, the US government has introduced a new policy which is very protective and requires all ships that enter its territory to follow certain conditions depending an the type of vessel. America has put forward a comprehensive proposal to the International Maritime Organization (IMO) which covers four categories: passenger ships, cargo vessels, mariners, and harbors. Probably because there is a pressure by the US from the inside and in order to avoid the superpower dictating what it wants in international relations, the agreement has been achieved that IMO will handle the implementation of new rules and new digital systems for passenger ships, the technology for which belong to the USA, the World Custom Organization (WCO) will handle the cargo vessels and ILO the mariners. ${ }^{10}$

$9 \quad$ Beside this problem there is the big question, especially in the Islamic world, as to whether it is possible that the attack was "done" by international terrorists to make America threaten countries where Moslems are in a majority and to show a more independent attitude towards the global scenario of America that gives lots of benefits to Israel.

10 The statement from Bush was supported by his Vice President Dick Cheney (Republika 22 and 24 January, 2004 p. 1 and 5). The future development is more interesting since the United Kingdom has refused Bush's invitation. Islamic countries are offended and feel worried by the recent action of the United States of America's government as 
The background to the US demand was "obscured" by the assumption that the ILO 108/1958 convention of Seafarer Identity Document (SID) was out of date from the security point of view. For that reason it was argued that the convention should be revised to accommodate new regulations related to modern security issues ${ }^{11}$ for the seafarer including the necessity of biometric template. ${ }^{12}$ On June 2003, ILO accepted the revision which is known as ILO Convention 185/2003 of Seafarers Identity Document (SID). This convention covers all the U.S. demands as started in Maritime Transportation Security Act of 2002-MTSA 2002,13 even though the legal construct is not completely in accord with US desires. ${ }^{14}$ As stated by Yuwono Sudarsono, this reality

stated by the Vice Prime Minister of Malaysia Najib Tun Razak (Republika, 24 January, 2004) International Labor Organization, Second Informal Special Sitting on Improved security of Seafarer's Identity Document, Geneva 17 October 2002 (SSSID/2002/2), p. 2.

11 SID should cover: 1) digital photograph, 2) the owner signature, 3) the authority of the publisher, 4) nation approved, 5) the positive identification of seafarer qualification, 6) the permission to enter another country, and 7) biometric template, International Labor Organization, Consultation Meeting on Improved Security of Seafarers Identification, Geneva, 9-10 May 2002 (CMISSI/2002) Appendix 2, Prevention and Suppression of Act of Terrorism against Shipping, Seafarer Identification Submitted by the United States, b. 2.

12 Biometric is any automatically measurable, robust and distinctive physical characteristic or personal trait that can be used to identify an individual or verify the claimed identity of an individual John D. Woodward, et. al, Biometric a look at Facial Recognition, (prepared for the Virginia State Crime Commission), Rand, 2003, Santa MonicaCalifornia, p. 1.

13 Therefore, the Department of Labor and Transportation, Department of Human Rights, Department of Foreign Affairs should formulate the national policy to protect the laborers who work in foreign ships. This formula should then be proposed by the Foreign Affairs Department to be an International Legal practice. This duty can also indicate the success of SBY-Kalla Regime. For the record, Indonesia has a Minister of Coordination since 1967 but this has not really worked. See the recent difference of opinion between Yusuf Anwar (Minister of Finance) with Sri Mulyani (Minister of National Planning Board) about Moratorium of Indonesia’s Debt. Public Law 107-295; Nov. 25, 2002.

14 Section 103 states that TREATY INITIATIVE-The secretary of the department in which the coast guard is operating is encouraged to 
has emphasized the fact that the super-power can infiltrate any of its interests which are "packed" in positive international legal format such as ILO convention 108/1958. ${ }^{15}$ The United States of America thinks that the ILO 108/1958 is not adequate from a security point of view because SID ${ }^{16}$ which is covered by ILO 108/1958 can easily be manipulated by irresponsible parties such as terrorists to attack the US and endanger its security and defense.

Section 103 (a) MTS 2002 asks the U.S government to negotiate the revision of ILO 108/1958 to prevent the manipulation of SID requirements in the interest of security. ${ }^{17}$ Section 103 (b) states that the U.S government is required to propose the design of new regulations to the Trade Committee, the Science and Transportation Senate and to the Committee of Transportation and Infrastructure of the House of Representative. If this design is approved by that Committee, it will create a uniform and comprehensive Identification System for Seafarers. ${ }^{18}$

negotiate an international agreement or amendment to an international agreement that provides for a uniform, comprehensive, international system of identity of any seafarer aboard a vessel within the jurisdiction, including the territorial waters, of the USA or such other country.

The U.S proposed that SID should cover 1) Positive and verifiable identification- "positive" means the document holder is the person whom the document was issued to, "verifiable" is the validation of authenticity of the document by source, 2) Uniformity- the document of a universal standard to ensure consistent application, 3) Acceptability- The development of a standard that is convenient, userfriendly, cost effective and does not impair commerce, 4) Reliabilitythe document of a standard that works constantly in a practical environment, 5) Security-the development of a standard that allows for the exchange of information is among member States to allow for verification and validation. Prevention and Suppression, op. cit, p. 7. Section 4 (3) states that SID should include a) full name (first and last name where applicable), b) date and place of birth, c) nationality, d) physical characteristics, e) photograph, f) signature or, if bearer is unable to sign, a thumbprint. Infra footnote.

The international political pattern evidenced by the US is supported by the congress, without doubt in order to ignore the international legal norms for as Morgenthau comments this country is independent in any relation with other nations and has modern technology which can force other countries or parties it is involved with, (see Morgenthau chapter VII and VIII). 
ILO convention 185/2003 contains some new regulations which were not covered in ILO 108/1956 such as: SID which can be read by specially designed machines; National Electronic Database which can be accessed at anytime, anywhere by an legal official; the quality control and the evaluation of SID; provision for land furlough, visit and transfer for seafarers; prolongation and withdrawal of SID.

The innovation of digital technology has been used to impose a system where the output is a SID for every seafarer in order to make the identification of every seafarer easier and to prevent the possibility of transferring a SID to someone else (in U.S. language terrorist). But it is no secret that with the excuse of protecting Intellectual Property Rights (IPR), people who use this technology are dependent on its creators. The question is: isn't it possible that the creator of this technology can “arrange” the data based on his purposes? Isn't it possible that this has become the starting point of the terrorist created by America? These questions are not impossible considering the ability of America to create a terrorist like $\mathrm{Al}$ Farouk while Indonesia has never known about the actions and the information gained by the U.S. from $\mathrm{Al}$ Farouk that point to him being a real terrorist. ${ }^{19}$

\section{THE IMPORTANCE OF ILO 185/2003}

Human resources have an important and strategic role in developing the oceans and fisheries of Indonesia. One of the human resources, with an important role, is the seafarer who dares to face all the dangers of nature. Working on a ship, whether passenger ship or freighter, needs a lot of courage in facing the challenge of nature. Such a person needs to be tough, disciplined, and able to live in a small community for a long term period of one to three months at sea, with the need to maintain harmonious relationships amongst the seafarers.

Nowadays the seafarer aboard a merchant vessel is required to meet the demand of Standard Training Certification and Watch-keeping

19 See the testimony of Frederich B. Bunk in the Abubakar Baasyir's Assembly (Tempo, 23 January 2005, p. 94-95). It is known that Umar Al Farouk escaped from Guantanamo, and was shot to death in one region in Iraq. This evidence has given rise to a big question whether this scenario has been prepared beforehand. 
for Seafarer 1995, whereas the seafarer aboard a fishing vessel is required to fulfill the Competence Standard of Standard Training Certification and Watch-keeping for Fishing Vessel Personnel (STCW-F) 1995 and IMO. The standard to be met by a seafarer includes knowledge and skill in saving lives and goods as well as the environment to ensure it is clean and free from pollution (clean ocean) and also to ensure responsible fishing.

To anticipate such certification, Indonesia has determined the qualification of the seafarer ${ }^{20}$ and the possession of a SID. It is estimated that the number of Indonesian seafarers is around 120,000. ${ }^{21}$ Such a large number has brought significant economic benefits and foreign exchange while unemployment has been reduced by sailors working on foreign ships.

Indonesian seafarers, who work on a ship which flies a foreign flag or an Indonesian flag and sails outside Indonesia territory, especially to and from the territory of the United States, get health and security guarantees if they have an SID as stated in ILO convention 185/2003. If the Indonesian seafarers have SID, it will be easier for the Indonesian Embassy to give protection and legal assistance. But the question arises in foreign relations as to: how the representative of the Indonesian Government can access the SID if one of its seafarers has a legal problem. ${ }^{22}$ Another important question is whether the representative of the Republic of Indonesia has the authority to extend the SID. If the representative can access and has authority to extend the SID, it will be easier for the Indonesian seafarer and the Indonesian Embassy in a foreign country to do their jobs. On the other hand, if they do not have such access authority, it will cause problems not only for the seafarers but also the Indonesian Embassy, especially if they have a legal problem and when the SID is out of date. For the seafarer, SID concerns job security

\footnotetext{
20 The stipulation of qualification and certification for the seafarer is arranged by the Government Regulation No. 7/2000 about Seafarers. Country with the second biggest number of seafarers in the world, after The Philippines.

22 The same problem is faced by Indonesia Laborers in a foreign country. Even though the Regulation No. 39/2004 gives protection to them and arranges various legal obligations of PJTKI and the partner in the foreign country, the mobility often can not be monitored by the representative of Indonesia.
} 
and safety, while for the representative of Indonesia it becomes a measurement of success as a foreign diplomat.

Therefore, the Indonesian government should find answers to these questions above. This relates to the consular function of the Indonesian representative for the Indonesian citizens who live in his area.

Accurate personal data in the SID will secure the seafarers from the suspicion and accusation of committing a terrorist and other criminal act. The security can be achieved if from the first, the entry data such as official birth certificate identity card and family card, match each other. Otherwise, the seafarer will be placed in a difficult situation that can cause suspicion and accusation. Therefore, accurate personal identity is really important for every seafarer.

\section{THE STEPS THAT SHOULD BE TAKEN}

In order to give security for Indonesian seafarers the following systematic steps related to the validity of information data should be taken.

\section{The Provision of a National Electronic Database}

The provision of a national electronic database is very important to apply the ILO 185/2003 convention. It can only be achieved if it is well planned from the first including which technology will be used. As far as possible dependence on the creator of that technology, operationally or in providing maintenance, should be avoided. Another important consideration is the provision of supporting facilities for setting up a national electronic database including capable and dedicated human resources.

\section{The Mechanism and Procedure for Ratification of the ILO convention 185/2003}

Generally the government of Indonesia has come to the conclusion that the ILO convention provides many benefits which is why 
Indonesia has agreed to ratify the ILO convention 185/2003. The decision was based on the study of two related state regulations namely the State regulation No. 24 of 2004 on International Agreement and the State Regulation (UU P.I) No.10 of 2004 on the making of State Rules and Regulations (UUP3), which give guidance for procedures and mechanism in approving an International Agreement either bilateral, regional or multilateral.

According to article 5 clause 1 of the State Regulation No. 24/ 2000, the steps that should be followed are (1):

a. The department for Labor and Transmigration holds an internal meeting to prepare a draft for an International convention that includes:

i. An academic document (states the background and goals and benefits of the convention for the country, government, and citizens). ${ }^{23}$

ii. The draft Regulation (the process, form and content should refer to UUP3)

iii. The certified copy of the convention

iv. A copy of the translation of the convention

b. The Minister of Labor and Transmigration submits a request to the Minister of Foreign Affairs for formal permission from the President and then,

c. The Minister of Labor and Transmigration starts to discuss the draft intensively in an Inter-Department committee.

d. The Minister of Labor and Transmigration sends letters to related Ministers and Heads of Organizations, with

$23 \quad$ The Department of Labor and Transmigration has just prepared the draft of an academic document which should be discussed first with the Department of Foreign Affairs, Department of Law and Human Rights and Academic Practitioners, and other components that have close relationships to the draft Regulation. 
the study results of the inter-department committee attached in order to get written support. Similar letters are sent to the Minister of Foreign Affairs to get the Presidential Decree.

e. The Minister of Foreign Affairs requests a Presidential decree by attaching one certified copy of the convention, one certified copy of the translation, 33 certified copies and the translation, the draft of State Regulation, and academic draft.

f. When the Presidential decree is published, the Minister of Law and Human Rights will forward the draft to the House of Representatives for further discussion at several levels before final approval.

g. When the draft is approved by the House of Representatives, it becomes a State Regulation and is given a number. It is, then documented in a State file by the Minister of Law and Human Rights. After that, the Minister of Law and Human Rights publishes an instrument of ratification to be sent thought the Representative of Indonesia in Geneva to the Director General of ILO as the depository of the ILO convention 185/2003.

Section 15 and 16 in P3 Regulation point 2.i state that the government and the House of Representatives (DPR) have agreed that the Regulation to legalize the ILO convention 185/2003, be included in the House of Representatives legislative program for the period 20042009.

From this explanation of how the ILO convention 185/2003 has been made law, it is clear that many institutions are involved even though the core business is that of the Department of Labor and Transmigration. ${ }^{24}$

$24 \quad$ The same thing occurred in composing the draft of regulation now Regulation No. 39/2004 giving protection to Indonesia Labor in a Foreign Country. 
The Department of Foreign Affairs also has an important role as the body who understands the philosophical meaning of the convention. Other institutions and departments also contribute much. An essential object of this mechanism is that the legalizing of the regulation should guard Indonesian interests to a maximum level. Moreover, the regulation should reflect the people as well as the Indonesian government as a whole and be an integral part of regulations to protect the Indonesian citizen in a foreign country.

The discussion of the draft regulation for ratification of the ILO convention 185/2003 should pay attention to the legal norms as stated in Regulation No. 39/2004 about the placement and protection of Indonesian labor in foreign countries. Such an integrated framework can reduce the weak legal status of overseas workers if they are forced into a legal dispute with their employer or with other people.

The above has given a brief description of the law making process including the legalizing of an International convention to be incorporated into the Indonesian legal system. However, this "mechanism” shows the weak bargaining position of this country in international relations. Actually, the elements of national power do not enhance Indonesia's international bargaining position. Thus, once again Yuwono Sudarsono is correct and we have reluctantly to accept that Indonesian foreign policy as set out in GBHN, is still a dream.

This condition should immediately be improved. As stated by Morgenthau, the population is a burden for Indonesia and as a result the country can not be involved effectively in International relations.

The effort to improve the quality of human resources is a huge job and will take a long time, but it should be done so that the foreign worker (TKI) and seafarer will have more dignity as the people of Indonesia become more educated. With better training, diplomats should be the ones who are able to give more effective protection to Indonesia citizens living abroad until the day comes when they have the ability and courage to defend and to protect themselves.

\section{Synchronization and Harmonization of National Regulations with the ILO Convention 185/2003}

Once the certificate of legalizing ILO convention 185/2003 has been registered with the Director General, the ILO convention will be 
active for six months. It is hoped that within those six months the synchronization and harmonization of National Regulations with the ILO convention 185/2003 will be completed. It is very important because if it is not done, there will be legal uncertainty for Indonesian seafarers in arranging their SID. However, the process of legalizing the ILO convention 185/2003 can be carried out simultaneously with the harmonization of National Regulations in order to save time.

\section{CONCLUSION}

Various bilateral agreements have been made by Indonesia with other countries in order to control the placement of Indonesia workers in foreign countries. To reduce the sensitivity of the receiving country, multilateral approaches to various International Organizations have been made. This should mean there is direct access for the representative of Indonesia to workers overseas whatever their jobs.

The effort of Indonesia to legalize the ILO convention 185/2003 should be used to give a more complete SID to its users (seafarers). On the one hand this gives a guarantee of protection for their rights, while on the other it makes it easier for the representative of the Indonesian government to monitor its citizens (WNI) who work in various foreign ships abroad and to give legal protection when it is needed.

For the United States of America, the revision of the ILO convention 185/2003 is used to prevent terrorists entering the country and disturbing its interests. For Indonesia, it should be a means to protect Indonesia's seafarers from subjective accusations by this super-power.

The legalizing of the ILO convention 185/2003 should be synchronized and harmonized with other regulations which relate to it such as Regulation No. 39/2004, Regulation No. 37/1999 and other relevant stipulations. 